\title{
The legacy of stockless organic conversion strategies
}

\author{
By D L SPARKES, A J ROLLETT \& P WILSON \\ Division of Agricultural and Environmental Sciences, School of Biosciences, University of \\ Nottingham, Sutton Bonington Campus, Loughborough, Leicestershire LE12 5RD, UK
}

\begin{abstract}
Summary
Huxham et al. (2005) reported the impacts of seven conversion strategies on the first organic crop (winter wheat). This paper investigates the effect of the conversion strategies on the second (winter beans) and third (winter oats) organic crops, thereby extending the analysis throughout the first complete rotation. Conversion strategy had a significant impact on organic bean yield, which ranged from 2.84 to $3.62 \mathrm{t} \mathrm{ha}^{-1}$ and organic oat yield, which ranged from 3.24 to $4.17 \mathrm{t} \mathrm{ha}^{-1}$. In the organic bean crop, weed abundance prior to harvest, along with soil texture, accounted for $70 \%$ of yield variation. For the oats, soil mineral nitrogen in November together with weed abundance in April, accounted for $72 \%$ of the variation in yield. Annual average gross margins, calculated over the two year conversion period and the first three organic crops, ranged from $£ 274$ to $£ 459 \mathrm{ha}^{-1}$.
\end{abstract}

Key words: Organic, conversion, stockless, beans, oats

\section{Introduction}

The ratio of fertility building to fertility exploiting cropping phases has a major influence on organic crop yields (Younie, Watson \& Squire, 1996), financial returns and hence the success of organic systems. During the conversion from conventional to organic farming the objective is to increase soil fertility usually through nitrogen $(\mathrm{N})$ fixed from grass clover leys. In a stocked system ley management is often through grazing and harvesting for hay and silage whereas in a stockless system legumes are usually cut and left as a mulch. The aim is to build up sufficient $\mathrm{N}$ in the system during the conversion period to support the subsequent rotation.

The ideal conversion crop will provide sufficient nitrogen (and other nutrients) for the following organic crops, facilitate improvements to soil structure and soil fertility, have good competitive ability against weeds and provide a good economic return. Conversion strategies that include cash cropping may give a better return in the short-term than a red clover green manure strategy but may impact negatively on crop yields, in the longer-term, later in the rotation. Typically, the financial returns of such systems being measured as output minus variable costs to provide gross margin (GM) measures. To date, research examining the longer-term viability of systems has focused upon rotations with a red clover green manure conversion strategy (Bulson et al., 1996; Cormack, 1999; Welsh et al., 2002). As a result, there is a need for robust, replicated studies of the longer-term impacts of alternative conversion strategies on subsequent organic crops. 
Building upon the work of Huxham (2003) the current study looks at the legacy of seven conversion strategies in terms of crop yield, and financial returns, weed burden and soil fertility. In particular, the paper presents the results from the second (winter beans) and third (winter oats) organic crops post conversion.

\section{Materials and Methods}

Conversion to organic status began on 20 hectares of Bunny Park, Nottinghamshire in August 1999. Within the site a 1.2 ha experimental area was established consisting of 28 plots (each 12.5 $\times 30 \mathrm{~m}$ ) which were sown with a red clover-ryegrass green manure on 5 September 1999. Seven conversion strategies were implemented and these were replicated four times in a randomised block design. Two of the conversion strategies were based on the previously sown red cloverryegrass green manure (RCRC and CSRC), and five other strategies were implemented in March 2000 (Table 1). Soil texture on the site ranged from sandy loam to sandy clay at a depth of 0-30 $\mathrm{cm}$. To account for this variation, blocking has been used (blocks 1 and 2 sandy loam and blocks 3 and 4 sandy clay). Conversion was completed in 2001 and a crop of organic wheat (Triticum aestivum) was planted over the entire experimental area. This was followed by the second (winter beans, Vicia faba) and third (winter oats, Avena sativa) organic crops which were the subject of the current experiment.

Winter beans (cv. Clipper) were sown on 8 December 2002 at 40 seeds $\mathrm{m}^{-2}$. Winter oats (cv. Dunkeld) were drilled on 9 October 2003 at 371 seeds $\mathrm{m}^{-2}$. Soil samples were removed using soil augers from pre-determined randomised locations in the experimental plots in September 2002, February and November 2003, and February and August 2004. Six cores were taken from each plot at $0-0.3,0.3-0.6$ and $0.6-0.9 \mathrm{~m}$ depths. Weeds were recorded along two $30 \mathrm{~m}$ line transects per plot, each $2 \mathrm{~m}$ from the plot edge. The species of each weed touching the transect line was recorded, together with the number of times that species was observed. Species composition and total weed number was monitored at five or six weekly intervals along the line transects from April to August 2003 and April to July 2004.

Crop yield was estimated on 19 August 2003 and 8 August 2004 using a plot combine harvester (Sampo Rosenlew 2010) on a previously un-sampled strip of the plot. The average area combined was $50.7 \mathrm{~m}^{2}$ for winter beans and $60.6 \mathrm{~m}^{2}$ for winter oats. A sub-sample of the combine yield was immediately oven dried at $80-85^{\circ} \mathrm{C}$ to determine moisture content.

All experimental data was analysed using an analysis of variance (ANOVA) or regression analysis in Genstat 8.1 for Windows. Where appropriate, data was transformed prior to analysis to meet the assumption of homogeneity of variance. To account for any differences in soil texture within the experimental blocks, percentage sand content of the soil was used as a covariate in the analyses of variance calculations. Gross margins were calculated based upon the experimental yields, using crop output prices from Lampkin et al. (2002), minus the variable costs incurred in the production of the crops.

\section{Results}

Winter bean yields from VEVR, UWRC, UWBP and CSRC were significantly higher $(P=0.008)$ than from WHBE and RCRC (Table 2). Winter oat yields from the clover based strategies were significantly larger than those from OABE and WHBE $(P=0.002)$. When percentage sand content of soil was used as a covariate in the analysis of variance, this had a significant effect on yield of oats $(P=0.017)$ but not beans, hence the adjusted yields are only presented for the oat crop. There was a highly significant relationship $(P<0.001)$ between weed number in August 2003 and winter bean yield (Fig. 1). Linear regression with groups showed that crops with the same number of weeds produced greater yields on sandy soil than on clay soil. In the oat crop, soil mineral 
Table 1. The conversion strategies were two-year cropping sequences, all followed by wheat in the third year. $广 A$ cut and mulched green manure; $u / s=$ undersown with red clover

\begin{tabular}{|c|c|c|}
\hline Strategy & First Year Conversion & Second Year Conversion \\
\hline RCRC & ${ }^{\dagger}$ red clover-ryegrass & ${ }^{\dagger}$ red clover-ryegrass \\
\hline VEVR & ${ }^{\dagger}$ hairy vetch & ${ }^{\dagger}$ hairy vetch-rye (cv. Mot \\
\hline CSRC & red clover (seed) -ryegrass & ${ }^{\dagger}$ red clover-ryegrass \\
\hline UWRC & $\mathrm{u} / \mathrm{s}$ spring wheat (cv. Paragon) & ${ }^{\dagger}$ red clover \\
\hline WHBE & spring wheat (cv. Paragon) & winter beans (cv. Clipper) \\
\hline OABE & spring oats (cv. Solva) & winter beans (cv. Clipper) \\
\hline UWBP & $\mathrm{u} / \mathrm{s}$ spring wheat (cv. Paragon) & $\begin{array}{l}\text { spring pea (cv. Agadir) - } \\
\text { spring barley (cv. Static) }\end{array}$ \\
\hline
\end{tabular}

NB. WHBE, OABE and UWBP- unlikely to be acceptable to certification bodies (experimental additions only).

Oat yield $=4.196-0.192 \times$ sqrt (weed no. $)+0.01837 \times \operatorname{SMN}(P<0.001), \mathrm{R} 2=0.72 \quad$ (Eqn 1$)$

Table 2. The effect of conversion strategy on winter bean and winter oat combine yield

\begin{tabular}{lccc}
$\begin{array}{l}\text { Conversion } \\
\text { Strategy }\end{array}$ & $\begin{array}{c}\text { Winter bean yield }(\mathrm{t} \\
\left.\mathrm{ha}^{-1}\right)\end{array}$ & $\begin{array}{c}\text { Winter oat } \\
\text { yield }\left(\mathrm{tha}^{-1}\right)\end{array}$ & $\begin{array}{c}\text { Winter oat yield (t ha-1) } \\
\text { adjusted for covariate \% sand }\end{array}$ \\
\hline RCRC & 2.78 & 3.76 & 3.92 \\
VEVR & 3.62 & 3.58 & 3.57 \\
CSRC & 3.34 & 4.17 & 4.17 \\
UWRC & 3.58 & 4.16 & 4.13 \\
OABE & 3.10 & 3.24 & 3.24 \\
WHBE & 2.84 & 3.33 & 3.35 \\
UWBP & 3.50 & 3.54 & 3.40 \\
& & & 0.002 \\
\hline P Value & 0.008 & & $0.230(17 \mathrm{df})$ \\
SED & $0.240(18 \mathrm{df})$ & &
\end{tabular}



Fig. 1. Linear regression of bean yield on $\ln$ (weed number) per line transect on 6 August. $\circ$ sand $\mathrm{y}=13.73-2.347 \mathrm{x} \ln \left(\right.$ weed no.); $\boldsymbol{a}$ clay $\mathrm{y}=14.38-2.347 \mathrm{x} \ln ($ weed no. $) . \mathrm{R}^{2}=0.70$ 
Table 3. Annual average gross margin (GM) for the two-year conversion period and the three-year organic rotation

\begin{tabular}{lcccccc}
\hline & $\begin{array}{c}\text { *Wheat } \\
\text { GM }\end{array}$ & Bean GM & Oat GM & $\begin{array}{c}\text { Annual average } \\
\text { GM, 3 organic } \\
\text { crops }\end{array}$ & $\begin{array}{c}\text { Annual average } \\
\text { GM, conversion } \\
\text { period \& 3 } \\
\text { organic crops } \\
£ \text { ha }^{-1}\end{array}$ & $\begin{array}{c}\text { Strategy rank } \\
\text { conversion period } \\
\& 3 \text { organic crops }\end{array}$ \\
\hline RCRC & 884 & 448 & 528 & 620 & 357 & 2 \\
VEVR & 551 & 616 & 499 & 555 & 291 & 5 \\
CSRC & 745 & 562 & 592 & 633 & 459 & 1 \\
UWRC & 698 & 608 & 592 & 633 & 352 & 3 \\
OABE & 533 & 512 & 445 & 497 & 310 & 7 \\
WHBE & 478 & 460 & 459 & 466 & 274 & 6 \\
UWBP & 430 & 592 & 493 & 505 & 277 & \\
\hline Mean & 617 & 543 & 515 & 558 & 331 & \\
\hline
\end{tabular}

* GM data from conversion period and first organic crop is drawn from Huxham (2003). Data presented in the absence of subsidies.

nitrogen (SMN) in November 2003 together with weed abundance in April 2004, accounted for $72 \%$ of the variation in yield (Eqn 1).

Average annual GMs were greatest for the 'fertility building' strategies, especially those based on red clover (Table 3). CSRC had the largest average GM ( $\left.£ 459 \mathrm{ha}^{-1}\right)$ and WHBE the smallest $\left(£ 274 \mathrm{ha}^{-1}\right)$.

\section{Discussion}

The OABE and WHBE strategies had the lowest yields in both the winter bean and winter oat crops. In the bean crop, yield was accounted for by weed number and soil texture, while the yield of oats was determined by a combination of weed competition and soil mineral nitrogen. Weed dynamics during the conversion period can have important implications for weed burden in the subsequent rotation (Albrecht and Sommer, 1998). Huxham (2003) measured differences in weed burden during the conversion period with the clover-based strategies having significantly less weed dry matter than, for example UWBP. By the end of the second year of conversion, significant differences in weed biomass were recorded with a tendency for the more exploitative strategies, OABE and WHBE, to have a greater weed biomass. This may have resulted in more weed seeds entering the seed bank than from the clover-based strategies; a finding reinforced by Younie et al. (2002) who noted that rotations with a higher proportion of grass-clover leys had consistently smaller weed seed banks than those with a higher proportion of cereal and vegetable crops.

CSRC had the largest gross margin, at $£ 459 \mathrm{ha}^{-1}$, outperforming all other strategies by at least $£ 102 \mathrm{ha}^{-1}$. However, this may be seen as a 'risky' strategy which is dependent on securing a market for clover seed and successful management of a clover seed crop. A risk-averse grower would be advised to adopt the strategy with the second highest average annual GM, RCRC ( $\left.3357 \mathrm{ha}^{-1}\right)$.

\section{Acknowledgements}

The support of the HGCA in funding this work is gratefully acknowledged. We also thank all individuals who assisted with the collection of the experimental data.

\section{References}

Albrecht H, Sommer, H. 1998. Development of the arable weed seed bank after the change from 
conventional to integrated and organic farming. Aspects of Applied Biology 51:279-288.

Bulson H A J, Welsh J P, Stopes C E, Woodward L. 1996. Agronomic viability and potential performance of three organic four-year rotations without livestock, 1988-1995. Aspects of Applied Biology 47:277-286.

Cormack W F. 1999. Testing a stockless arable organic rotation on a fertile soil. In Designing and Testing Crop Rotations for Organic Farming: Conference Proceedings, pp. 115-123. Eds J E Olesen, R Eltun, M J Gooding, E S Jensen and U Köpke. Denmark: Danish Research Centre for Organic Farming.

Huxham S K. 2003. Organic conversion strategies for stockless farming. Ph.D. Thesis, University of Nottingham.

Huxham S K, Sparkes D L, Wilson P. 2005. The effect of conversion strategy on the yield of the first organic crop. Agriculture, Ecosystems and Environment 106:345-357.

Lampkin N, Measures M, Padel S. 2002. 2002/03 Organic Farm Management Handbook. 5th Edn. Aberystwyth: University of Wales and Berkshire: Organic Advisory Service.

Welsh J P, Phillips L, Cormack W F. 2002. The long-term agronomic performance of organic stockless rotations. In Proceedings of the Colloquium of Organic Researchers Conference, 26-28 March 2002, pp. 47-50. Ed. J Powell. Aberystwyth: University of Wales.

Younie D, Watson C A, Squire G R. 1996. A comparison of crop rotations in organic farming: agronomic performance. Aspects of Applied Biology 47:379-382.

Younie D, Taylor D, Coutts M, Matheson S, Wright G, Squire G. 2002. Effect of organic crop rotations on long-tem development of the weed seedbank. In Proceedings of the Colloquium of Organic Researchers Conference, 26-28 March 2002, pp. 215-220. Ed. J Powell. Aberystwyth: University of Wales. 